The Domestic Political Roots of U.S. Perspectives on the International Law on the Use of Force

\begin{abstract}
This article attempts to demonstrate the connections between US executive war powers, US interpretations of the international law on the use of force, and the history of US war-making and war-fighting, both at home and abroad. It begins by discussing the status of presidential war powers in the US domestic context, before examining the centrality of national security in US political life. In arguing that the imperial character of U.S. international legal interpretation and defence policy changes very little between Democratic and Republican administrations, regardless of the 'legality' of relevant actions subject to the international law on the use of force, this paper illustrates that U.S. 'exceptionalism' is situated not in a sphere outside the international rule of law, but rather in an exceptional space within an international legal system that privileges the powerful.
\end{abstract}

\title{
INTRODUCTION
}

The political literature on the United States is divided on the extent to which US foreign policy is impacted by the political party which holds the Presidency, and often co-exists with assumptions that Democratic Presidents are more supportive of multilateralism and upholding the rule of law. As a small, officially neutral country, that supports an ordered, multilateral world system, and also one with close ties to the USA, the attitude of the US President to questions of the rule of law in international conflicts is of vital strategic importance to Ireland. It is the role of the USA in conflicts abroad which has been the most common source of friction in Ireland on American foreign policy, most recently seen in the protests and debate around the 
use of Shannon airport by the US military en route to Iraq. This article examines the extent to which US military action abroad is a product of exceptional circumstances or particular presidents, or alternatively whether it is an integral part of the perceived, necessary, function of the US presidency, built into the core political and legal structure of the state.

The United States has been involved in war continuously since the foundation of the state, to the extent that war is embedded in American culture to the point that it is a feature of everyday life. ${ }^{1}$ The set of founding beliefs which are an integral part of the American mythos, are both based on 'universal' ideas of 'freedom, equality, justice and humanity', ${ }^{2}$ and a high level of concern with militancy and national security, on which American exceptionalism is founded. ${ }^{3}$ The global military supremacy that the United States enjoys - and is committed to perpetuating - has become so central to the state's identity that the U.S. views itself as an exceptional state, and believes it is also a state that can exempt itself from the international legal system and the rule of law. ${ }^{4}$ The US also frequently pays creative lip service to the interpretation of existing legal rules, even though it is willing to flout others. ${ }^{5}$ In acting in this way, U.S. 'exceptionalism' is situated not in a sphere outside the international rule of law, but rather in an exceptional space within an international legal system that privileges the powerful. The international legal system is not a level playing field, in which all states are 'free' and 'equal', and only the most powerful states - those with the biggest 'markets' and the largest reservoirs of resources - can

\footnotetext{
1 Marilyn B. Young, "I was thinking, as I often do these days, of war": The United States in the Twenty-First Century' Diplomatic History 36 (1) (2012), 1-15: 1; Mary L. Dudziak, 'Death and the War Power' Yale Journal of Law and the Humanities 30 (1) (2017) 25-61: 32; Michael Sherry, 'War as a way of life' Modern American History 1 (1) (2018), 93-96: 96.

${ }^{2}$ Ed Lock, 'The Complex Fate of Being America: The constitution of identity and the politics of security', in Kenneth Christie (ed.) United States Foreign Policy and National Identity in the $21^{\text {st }}$ Century (London, 2008), 66-82: 70.

${ }^{3}$ Lock, 'The Complex Fate of Being America', 72.

${ }^{4}$ Andrew J. Bacevich, The New American Militarism: How Americans are Seduced by War (Oxford and New York, 2005) 1.

${ }^{5}$ Ian Hurd, 'The Empire of International Legalism' Ethics \& International Affairs 32 (3) (2018), 265-278: 266
} 
get away with resisting some of the rules they so rigorously enforce amongst their peers. ${ }^{6}$ When 'a strong state has influence over what the law says ... [1]aw and power become entangled by this process...' to the advantage of the powerful, and this is especially evident in the international law on the use of force. ${ }^{7}$

Political power is 'a force that continuously informs the creation, interpretation and enforcement of international law', ${ }^{8}$ yet 'interpretative disputes and their outcomes' are not presented as a 'function of power but simply as a result of unclear texts that are a product of compromises arrived at during the course of international negotiations. ${ }^{9}$ As a result, states usually act lawfully - because 'a complete mismatch between the rules of international law and the interests and practices of powerful states is rare', and 'violation is not a frequent event.'10

Demonstrating that in law, 'all depends on politics' does not mean that the political character of law cancels out law's legal character. It emphasises that there will be an 'inevitable moment of choice in legal practice in favour of one contested meaning against another' and, typically, this choice favours the interests of the powerful. ${ }^{11}$ The politics of choosing between different legal interpretations can be seen in, for example, U.S. attempts to create a right of pre-emptive self-defence in international law, in establishing the category of 'unlawful combatant,' and in the naming of the tactic of 'targeted killing', as used by Republican President George W. Bush and Democratic President Barack Obama in recent years.

\footnotetext{
${ }^{6}$ Rose Parfitt, 'Fascism, Imperialism and International Law: An Arch Met a Motorway and the Rest is History' Lieden Journal of International Law 31 (3) (2018), 509-538: 528 and 515.

${ }^{7}$ Hurd , 'The Empire of International Legalism', 274.

${ }^{8}$ B.S. Chimni, 'An outline of a Marxist course on public international law', in Susan Marks (ed.), International Law on the Left: Re-examining Marxist Legacies (Cambridge and New York, 2008), 53-91: 56.

${ }^{9}$ Chimni, 'An outline of a Marxist course on public international law', 54.

${ }^{10}$ Chimni, 'An outline of a Marxist course on public international law', 65.

${ }^{11}$ Martti Koskenniemi, 'What should international lawyers learn from Karl Marx?', in Susan Marks (ed.), International Law on the Left: Re-examining Marxist Legacies (Cambridge and New York, 2008), 30-52: 45.
} 
In the US context, this tension between the interpretation of law and political power is most commonly debated in the context of the U.S. debate on the separation of powers. It is relevant to 'international legal practice on the use of force, because it influences U.S. practice and the United States plays an outsized role internationally with regard to the use of force'. ${ }^{12}$ The accumulation of war-making powers in the US Executive Branch has direct consequences for the creation of customary international law on the use of force, for the interpretation of treaty rules regarding the use of force, and the interpretation of rules governing any uses of that force, as there is very limited domestic oversight by either the US Courts or Congress. It is therefore important to understand the division of war-making powers within the U.S. federal government, as this is 'crucial for understanding how the United States conceptualizes and engages with international law on the use of force' and, as the world's most powerful military actor, the US therefore has a significant capacity to frame and influence international law on the use of force. ${ }^{13}$

\section{PRESIDENTIAL WAR POWERS IN THE UNITED STATES}

'The circumstances that endanger the safety of nations are infinite, and for this reason no constitutional shackles can wisely be imposed on the power to which the care of it is committed. ${ }^{\prime 14}$

In theory, war-making powers in the U.S. are divided between Congress and the Executive Branch, as the Executive Branch's ability to approve the use of force is constrained by Congressional powers. Under the division of the war powers of the U.S. federal government

\footnotetext{
${ }^{12}$ Curtis A. Bradley and Jean Galbraith, 'Presidential War Powers as an interactive dynamic: international law, domestic law, and practice-based legal change' NYU Law Review 91 (4) (2015), 689-761: 697.

${ }^{13}$ Bradley and Galbraith, 'Presidential War Powers as an interactive dynamic', 748.

${ }^{14}$ Federalist No. 23. Available at: https://www.congress.gov/resources/display/content/The+Federalist+Papers
} 
according to the U.S. Constitution, the President is the Commander in Chief of the armed forces, as is stipulated in Article II, but it is Congress that has the power to declare war, and to raise and support the armed forces, according to Article I. ${ }^{15}$ The difference in language between Article I and Article II means that Congressional powers are seen as 'exhaustive', with Congress not allowed to do more than enumerated, while the illustrated powers for the Executive Branch are seen as 'illustrative', 'implying the existence of powers not specifically mentioned in the government's written charter. As a result, those who advocate for increased presidential war making rely on this distinction to justify such Presidential power. ${ }^{16}$ There is substantial debate as to the exact scope of Executive Branch power as it relates to national security, given that the U.S. constitution contains only a limited discussion of and reference to those powers, ${ }^{17}$ and neither the term 'national security' nor 'foreign affairs' is used or referred to in the text of the constitution. ${ }^{18}$

In the view of Gonzales (who acted as legal counsel to the Bush administration between 20012005), from 'a strict construction of the Constitution's text... the President cannot declare war', and 'one can argue that the President has no authority (beyond acting in self-defense) to initiate force or engage in military operations unless authorized by Congress to do so'. However, war power roles have become 'increasingly murky' due to Congress' 'frequent reluctance and

\footnotetext{
${ }^{15}$ Library of Congress, 'War Powers', 27 November 2017, available at: https://web.archive.org/web/20171130174502/https://www.loc.gov/law/help/war-powers.php (20 October 2020).

${ }^{16}$ Peter Haas, 'Does It Even Work? A Theoretical and Practical Evaluation of the War Powers Resolution' Congress \& the Presidency 44 (2) (2017), 235-258: 238.

${ }^{17}$ Alberto R. Gonzales, 'Advising the President: The Growing Scope of Executive Power to Protect America' (2015) Harvard Journal of Law and Public Policy 38 (2) (2015), 453-507: 457. Gonzales identifies the three sources of presidential power most commonly cited by judges and scholars relating to the areas of national security and foreign affairs: 'authority expressly granted by the U.S. Constitution'; 'authority granted by Congress by statute or through a declaration of war or authorization to use force'; and 'inherent or implied authority emanating from the Constitution.' Even in the case of that authority expressly granted by the Constitution and authority granted by Congress, however, Gonzales writes that:

'...while the text of the Constitution or a congressional statute may appear unambiguous, the authority of the Executive Branch to exercise discretion in the execution of our laws affords the President great flexibility. This in turn often gives rise to disagreements between the elected branches over the scope of power even when a statute or the Constitution appears unambiguous on its face.'

${ }^{18}$ Gonzales, 'Advising the President', 453.
} 
failure to act', the judiciary's 'inclination to demur', and, according to Gonzales, the increasing number of severe threats 'requiring decisive and rapid responses that only the President can provide.' ${ }^{19}$ This lack of clarity is based on the wording of the constitution, which, while stating that Congress has the power to declare war, does not state that military force can only be authorised or used in situations of war. ${ }^{20}$

It has generally been agreed historically that the Executive Branch has the authority to respond in self-defence to an attack, and to take defensive measures in the face of an imminent threat. ${ }^{21}$ To assume that these are the only circumstances in which a president may authorise the use of force today would be erroneous, but the extent to which presidents have a unilateral right to order the use of force is contentious. Haas identifies two major schools of thought regarding the subject of prerogative power and war powers. The first 'suggests that the president rightfully retains war-making powers independent of strict legislative approval by way of inherent powers', while the second argues that 'the Constitution leaves much less discretion to the president in the execution of the war power.' ${ }^{22}$

Some of the principal proponents of the first approach have included John Yoo, former deputy assistant attorney general in the Office of Legal Counsel during the George W. Bush administrations (and author of the 'Torture memos', which asserted that the Geneva Conventions were not applicable to the U.S. in the 'war on terror'), and former Supreme Court Justice and Assistant Attorney General, William H. Rehnquist. ${ }^{23}$ Yoo has argued that 'the Framers created a framework designed to encourage presidential initiative in war', with the

\footnotetext{
${ }^{19}$ Gonzales, 'Advising the President', 458.

${ }^{20}$ Michael Ramsey, 'Textualism and War Powers', The University of Chicago Law Review 69 (4) (2002), 15431638: 1544

${ }^{21}$ Gonzales, 'Advising the President', 460.

${ }^{22}$ Haas, 'Does It Even Work?', 240.

${ }^{23}$ The New York Times, 'A guide to the memos on torture' (2002), available at: https://archive.nytimes.com/www.nytimes.com/ref/international/24MEMO-GUIDE.html (20 October 2020).
} 
constitution consciously designed to provide 'elasticity' in the war powers process. ${ }^{24}$ Rehnquist envisioned a 'core of exclusive presidential commander in chief authority', with Congress having the power 'in certain situations to restrict the President's power as Commander in Chief to a narrower scope than it would have had in the absence of regulations. ${ }^{25}$ Ramsey, on the other hand, writes: 'the original war powers design, as we are able to understand it today, is best described as a core of exclusive congressional power surrounded by an area of arguable independent presidential authority', though this area of independent presidential authority is one which leaves the executive with 'substantial plausible avenues to justify the independent use of force. ${ }^{26}$ For example, an opinion from the White House's Office of Legal Counsel (OLC) of 1970, written by Rehnquist to defend the lawfulness of President Nixon's decision to deploy U.S. ground and air forces into Cambodia for the purpose of destroying base camps in use as supply depots and sanctuaries by the North Vietnamese and Viet Cong, offers a broader interpretation of executive war-making powers. ${ }^{27}$ In Rehnquist's opinion, the Constitution accommodates two interests: 'the prohibition of one-man commitment of a nation to war and the need for prompt executive response to international situations', and that 'in changing the original wording from the power of Congress to make war to the power of Congress to declare war', the "Founding Fathers" intended to distinguish between the initiation of armed conflict, which is for Congress to determine, and armed response to conflict situations, which the Executive may undertake. ${ }^{28}$

\footnotetext{
${ }^{24}$ John C. Yoo, 'The Continuation of Politics by Other Means: The Original Understanding of War Powers', California Law Review 84 (2) (1996), 167-305: 167 and 305.

${ }^{25}$ H. Jefferson Powell, Targeting Americans: The Constitutionality of the U.S. Drone War (Oxford University Press 2016) 101-102.

${ }^{26}$ Michael Ramsey, 'Constitutional War Initiation and the Obama Presidency', American Journal of International Law 110 (4) (2016), 701-717: 705.

${ }^{27}$ U.S. Department of Justice, Presidential Authority to Permit Incursion Into Communist Sanctuaries in the Cambodia-Vietnam Border Area, (14 May 1970). Available at: https://web.archive.org/web/20131014113201/http:/www.justice.gov/olc/1970/cambodia-1.pdf. ${ }^{28}$ Ibid.
} 
Today, it is generally accepted that the President may also use military force without prior permission from Congress in the case of an emergency, in order to protect citizens or repel an invasion. ${ }^{29}$ Congress has used full Declarations of War only sparingly, and instead has tended to authorise the president to use military force for specific instances through a statute, an example of which is the 2001 AUMF authorising the use of force against those responsible for the $9 / 11$ attacks. ${ }^{30}$

As the United States became more powerful and increased its military reach, it established a 'large permanent military less dependent on the Congress to raise funds for action,', and presidents and lawmakers began to interpret the prerogatives of the Commander-in-Chief more broadly.' ${ }^{31}$ Largely motivated by the United States' involvement in the conflicts in Korea and Vietnam - 'two long and unpopular wars' - Congress 'acted to reclaim its war-making authority' from the President. ${ }^{32}$ Congress was largely unsuccessful in its attempts to rein in presidential power, although it did pass the War Powers Resolution (WPR) in 1973, over President Richard Nixon's veto. ${ }^{33}$ The WPR was intended to:

'insure that the collective judgment of both Congress and the president will apply to the introduction of United States into hostilities, or into situations where imminent

\footnotetext{
${ }^{29}$ Shoon Murray, The Terror Authorization: The History and Politics of the 2001 AUMF (Palgrave Macmillan 2014) 11.

${ }^{30}$ Shoon Murray, The Terror Authorization, 12-13. Murray further notes that while the U.S. has engaged in armed conflict 'hundreds' of times, authorizations from Congress number in the dozens; however, prior to WWII, the majority of these instances of 'armed conflict' were 'brief Navy or Marine actions to protect U.S. citizens or promote U.S. interests.'

${ }^{31}$ Shoon Murray, The Terror Authorization, 13. It did so partially on foot of a report by the Senate Foreign Relations Committee which said that 'Congress's failure to challenge executive claims to the war powers' was " "probably the singly fact most accounting for the speed and virtual completeness of the transfer" of authority and initiative'. Failure to challenge the Executive Branch had led to Congress " giving away that which is not it's to give, notably the war power, which the framers of the Constitution vested not in the executive but, deliberately and almost exclusively, in the Congress." See: Andrew Rudalevige, The New Imperial Presidency: Reviving Presidential Power after Watergate (Ann Arbor, 2006) 117

${ }^{32}$ Shoon Murray, The Terror Authorization, 13.

${ }^{33}$ Shoon Murray, The Terror Authorization, 13.
} 
involvement in hostilities is clearly indicated by the circumstances, and to the continued use of such forces in hostilities or in such situations. ${ }^{34}$

This resolution asserts that the constitutional powers of the President as Commander-in-Chief to introduce U.S. armed forces into hostilities are exercised only pursuant to a declaration of war, specific statutory authorization, or a national emergency created by attack upon the United States, its territories or possessions, or its armed forces. ${ }^{35}$ The majority view in Congress was that 'flexibility has become a euphemism for presidential domination' and the 'nation's ability to make decisive choices, they stressed, was not equivalent to the president's ability to do so. ${ }^{36}$ Since Nixon, all U.S. presidents have 'consistently taken the position that the War Powers Resolution is an unconstitutional infringement upon the power of the Executive Branch'. ${ }^{37}$ The Resolution has not been effective, and subsequent U.S. presidents have approved the use of military force without prior Congressional approval; the most recent example being President Trump's assassination of Iranian General Qasem Soleimani in Iraq in January 2020. ${ }^{38}$

U.S. courts 'have not been willing to adjudicate challenges to purported presidential noncompliance with the War Powers Resolution. ${ }^{39}$ While presidents can deploy troops for short-term interventions of less than sixty days (having notified Congress within the first 48 hours of the deployment), under the WPR, these troops are supposed to return home to the U.S.

\footnotetext{
${ }^{34}$ H.J.Res 542 Public Law 93-148 Joint Resolution Concerning the war powers of Congress and the President (War Powers Resolution), available at: https://web.archive.org/web/20171130180346/https://www.govinfo.gov/content/pkg/STATUTE87/pdf/STATUTE-87-Pg555.pdf (20 October 2020).

${ }^{35}$ HJ. Res 542 Public Law 93-148.

${ }^{36}$ Andrew Rudalevige, The New Imperial Presidency, 118.

${ }^{37}$ Library of Congress, 'War Powers' (2017)

$<$ https://web.archive.org/web/20171130174502/https://www.loc.gov/law/help/war-powers.php $>$, accessed 30th November 2018.

${ }^{38}$ BBC News, 'Qasem Soleimani: US strike on Iran general was unlawful, UN expert says', 09 July 2020, available at: https://www.bbc.com/news/world-middle-east-53345885 (20 October 2020). See also: The New York Times, 'U.S. strike in Iraq kills Qassim Suleimani, Commander of Iranian Forces', 09 July 2020, available at: https://www.nytimes.com/2020/01/02/world/middleeast/qassem-soleimani-iraq-iran-attack.html (20 October 2020).

${ }^{39}$ Curtis A. Bradley, International Law in the U.S. Legal System (Oxford and New York, 2015), 298.
} 
if Congressional approval has not been granted by the time the sixty-day mark has been reached. In practice, however, 'presidents have used loopholes, saying that deployed troops are not involved in "hostilities" 40 , and courts have "reasoned that the meaning of "hostilities" in the Resolution...is a nonjusticiable political question that must be worked out by Congress and the Executive Branch rather than the courts. ${ }^{, 41}$

The WPR also includes an obligation on presidents to submit a report to Congress 'within 48 hours of any introduction of armed forces into hostilities or conditions where hostilities are likely to occur, along with details of the reason(s), circumstances, and authorities relevant to his decision.' Between 1973 and 2019, according to the War Powers Resolution Reporting Project, presidents submitted 48-hour reports under the WPR 105 times. ${ }^{42}$ Aside from this obligation, presidents tend to ignore the WPR, suggesting that 'by and large, the WPR serves little purpose other than as a mechanism to force the president to report to Congress on his intentions to use force, or that he had already done so. ${ }^{43}$

On $13^{\text {th }}$ December 2018, the Senate invoked the WPR for the very first time when it passed a resolution calling for an end to U.S. military aid to the Saudi-led coalition fighting in the conflict in Yemen. As was expected, this vote was largely symbolic - despite passing through both houses of Congress with bipartisan support, President Trump vetoed the joint resolution in April 2019. ${ }^{44}$ The president also vetoed a further attempt to introduce an Iran War Powers resolution in May 2020. ${ }^{45}$

\footnotetext{
${ }^{40}$ Murray, The Terror Authorization, 15.

${ }^{41}$ Bradley, International Law in the U.S. Legal System, 298.

${ }^{42}$ War Powers Resolution Reporting Project, Key Findings and Analysis, 2020, available at: https://warpowers.lawandsecurity.org/findingsandanalysis/ (20 October 2020).

${ }^{43}$ Haas, 'Does It Even Work?', 244.

${ }^{44}$ The New York Times, 'Trump vetoes measure to force end to U.S. involvement in Yemen war', 16 April 2019, available at: https://www.nytimes.com/2019/04/16/us/politics/trump-veto-yemen.html (20 October 2020). 45 The New York Times, 'Trump vetoes measure demanding Congressional approval for Iran conflict', 06 May 2020, available at: https://www.nytimes.com/2020/05/06/us/politics/trump-vetoes-iran-war-powers.html (20 October 2020).
} 
The executive branch now claims a wide range of powers related to war-making, and to the interpretation of relevant international law, with contentious action in the area of the use of force consistently supported by those legal opinions drafted by the White House's Office of Legal Counsel (OLC); as Arzich notes, the OLC presents its client - namely, the president with 'the best view of the law' to suit the political purposes of the executive of which it is part'46 essentially acting as the 'keeper of the presidential fig-leaf' ${ }^{47}$

Recent history is replete with executive branch assertions of unilateral presidential power in the area of war and the use of force. While Congress ultimately passed both the 2001 and 2002 AUMFs at the request of the Bush administration, Bush's legal counsel had nonetheless argued that it was 'beyond question' that the president had the 'plenary constitutional power' to 'take such actions as he deemed necessary and appropriate to respond to the terrorist attacks upon the United States on September 11, 2001', contending that neither the WPR, nor the 2001 AUMF, 'can place any limits on the President's determinations as to any terrorist threat, the amount of military force to be used in response, or the method, timing, and nature of the response', concluding that under the U.S. Constitution, such decisions 'are for the President alone to make. ${ }^{48}$

In 2011, President Obama commenced military action in Libya absent the permission of Congress, with the OLC arguing that ' $[\mathrm{T}]$ he President had the constitutional authority to direct the use of military force in Libya because he could reasonably determine that such use of force was in the national interest. Prior congressional approval was not constitutionally required to

\footnotetext{
${ }^{46}$ Luis Leon Arzich, 'Anatomy of a Failure: The War Powers Resolution as Law on the Books and Law in Action', UA Little Rock Law Review 42 (3) (2020), 425-484: 459.

${ }^{47}$ Eric Posner and Adrian Vermeule, 'Libyan Legal Limbo', 28 June 2011, available at: https://today.law.harvard.edu/vermeule-on-slate-com-libyan-legal-limbo/ (20 October 2020).

${ }^{48}$ The United States Department of Justice, 'The President's Constitutional Authority to Conduct Military Operations Against Terrorists and Nations Supporting Them', 25 September 2001, available at: https://www.justice.gov/sites/default/files/olc/opinions/2001/09/31/op-olc-v025-p0188_0.pdf (20 October 2020).
} 
use military force in the limited operations under consideration. ${ }^{49}$ This same OLC memo further notes that, as earlier opinions of the OLC have demonstrated:

'[T]he President also holds "the implicit advantage . . . over the legislature under our constitutional scheme in situations calling for immediate action," given that imminent national security threats and rapidly evolving military and diplomatic circumstances may require a swift response by the United States without the opportunity for congressional deliberation and action. ${ }^{50}$

In 2014, President Obama justified strikes against ISIS in Iraq as 'pursuant to my constitutional authority to conduct U.S. foreign relations and as Commander in Chief and Chief Executive. ${ }^{51}$ Later, his administration argued also had to authority to carry out these strikes under the 2001 AUMF, adding that while President Obama would 'welcome Congressional action to support the Administration's efforts against ISIL', it was not their assessment that any new authorization was required..$^{52}$

President Trump's assassination of Soleimani in January 2020, and his unauthorised strikes on Syria in both 2017 and 2018, are further examples of the broad remit assumed by the executive branch in the area of the use of force, with Congress seemingly powerless to halt military action.

Ingber argues that international law itself is regularly invoked as an enabling force within the U.S. domestic legal system, where the U.S. executive uses international law to:

\footnotetext{
49 The United States Department of Justice, 'Authority to Use Legal Force in Libya', 01 April 2011, available at: https://www.justice.gov/file/18376/download (20 October 2020).

${ }^{50}$ Authority to Use Legal Force in Libya.

${ }^{51}$ The White House, 'Letter from the President: War Powers Resolution regarding Iraq', 17 August 2014, available at: https://obamawhitehouse.archives.gov/the-press-office/2014/08/17/letter-president-war-powersresolution-regarding-iraq (20 October 2020).

52 The New York Times, 'White House invites Congress to approve ISIS strikes, but says it isn't necessary', 10 September 2014, available at: https:/www.nytimes.com/2014/09/11/world/middleeast/white-house-invitescongress-to-approve-isis-strikes-but-says-it-isnt-necessary.html (20 October 2020)
} 
'support expansive interpretations of statutory or constitutional grants of authority; to narrow statutory or constitutional prohibitions on executive action...; and to justify the displacement of the ordinary operation of domestic legal rules, at times with the effect of exchanging the ordinary domestic legal architecture for a more permissive framework based in international law. ${ }^{, 53}$

This empowerment phenomenon not only 'facilitates the Executive's aggrandizement of its own authority; at times it affirmatively induces it to do so. ${ }^{54}$ Ingber's examination of presidential referencing of international law to expand executive power, and as a 'limiting principle' in the area of the 2001 AUMF and targeted killing, are particularly relevant. ${ }^{55}$ In both cases, international law was used to provide legitimacy for executive branch action. It was then used to assert the Executive's 'wartime authority to act, at a minimum, to the limits of international law. ${ }^{56}$ The result of this empowerment phenomenon has been to create an 'executive-inferred exception' to domestic constraints, 'shaped by an international law standard that the Executive defines. ${ }^{57}$ Consequently, if an administration interprets international law in a permissive rather than a limiting fashion, as was the case with the Trump administration's assassination of Soleimani, then the executive is also likely to take a similar approach in interpreting its war powers. ${ }^{58}$

\footnotetext{
${ }^{53}$ Rebecca Ingber, 'International Law Constraints as Executive Power' Harvard International Law Journal 57 (1) (2016), 49-110: 55.

54 Ingber, 'International Law Constraints', 56.

55 Ingber, 'International Law Constraints', 51.

56 Ingber, 'International Law Constraints', 88.

${ }^{57}$ Ingber, 'International Law Constraints', 70.

${ }^{58}$ For further examination of the Trump administration's legal reasoning on this matter, and its contravention of relevant international law, see, for example: Adil Ahmad Haque, 'U.S. legal defense of the Soleimani strike at the United Nations: a critical assessment', 10 January 2020, available at: https://www.justsecurity.org/68008/us-legal-defense-of-the-soleimani-strike-at-the-united-nations-a-critical-assessment/ (20 October 2020), and United Nations, A/HRC/44/38 Report of the Special Rapporteur on extrajudicial, summary or arbitrary executions (targeted killings through armed drones and the case of Iranian General Quassem Soleimani), 15 August 2020, available at: https://www.ohchr.org/EN/Issues/Executions/Pages/AnnualReports.aspx (20 October 2020). For discussion of constitutional war powers and the Soleimani strike, see for example: Stephen Pomper, 'The Soleimani strike and the case for war powers reform', 11 March 2020, available at:
} 
The accumulation of war-making powers in the executive branch is a matter of concern for the international law on the use of force, as decisions taken by U.S. presidents to use armed force abroad against states and non-state actors directly implicate this law. As the exercise of the nation's foreign affairs is a matter for the executive branch, the president has the power to interpret, and to inform the creation of, international law, and U.S. courts have granted 'substantial deference to the President' on 'both the substance and form' of international law. ${ }^{59}$ Given the increasing power of the executive branch over issues of war-making and uses of force, this is particularly concerning for the international law on the use of force.

The president exercises significant control over the US interpretation and use of international law, without any systemic regulatory or judicial oversight 'to guide or review the exercise of presidential discretion in this context.' ${ }^{60}$ Presidents 'have come to dominate the creation, alteration, and termination of international law for the United States, ${ }^{61}$ as has been demonstrated, for example, by President Trump's unilateral decision to remove the United States from the Iran nuclear deal. ${ }^{62}$ 'However limited the President's domestic law-making authority may be', writes Weisburd, 'he clearly has considerable authority to create legal effects in the international context. ${ }^{63}$ This presidential control is of particular concern in the area of customary international law, where the 'vast majority' of relevant U.S. governmental practice for customary international law is executive branch practice, ${ }^{64}$ and where 'the President almost always decides the U.S. view on CIL... and is able to affect CIL both through

\footnotetext{
https://www.justsecurity.org/69124/the-soleimani-strike-and-the-case-for-war-powers-reform/ (20 October 2020).

${ }^{59}$ Oona Hathaway, 'Presidential Power over International Law: Restoring the Balance' The Yale Law Journal 119 (2) (2009), 140-268: 145.

${ }^{60}$ Curtis A. Bradley and Jack L. Goldsmith, 'Presidential Control over International Law' Harvard Law Review 131 (5) (2018), 1201-1297: 1203.

${ }^{61}$ Bradley and Goldsmith, 'Presidential Control', 1203.

${ }^{62}$ The Guardian, 'Iran deal: Trump breaks with European allies over 'horrible, one-sided' nuclear agreement', 9 May 2018, https:/www.theguardian.com/world/2018/may/08/iran-deal-trump-withdraw-us-latest-news-nuclearagreement (20 October 2020).

${ }^{63}$ Arthur M. Weisburd, 'The Executive Branch and International Law' (1988) Vanderbilt Law Review 41(6) (1988) 1205-1269: 1253.

${ }^{64}$ Bradley and Goldsmith, 'Presidential Control over International Law',1207.
} 
affirmative actions and statements and through decisions about whether to acquiesce in the practices and statements of other nations. ${ }^{65}$ Weisburd notes that '...to the extent the United States participates in the formation of customary international law, it does so largely through the President's acts. ${ }^{66}$ The U.S. Supreme Court's Banco Nacional de Cuba v. Sabbatino decision noted:

'When articulating principles of international law in its relations with other states, the Executive Branch speaks not only as an interpreter of generally accepted and traditional rules, as would the courts, but also as an advocate of standards it believes desirable for the community of nations and protective of national concerns.' 67

This is not to say, of course, that enhanced or increased Congressional involvement with U.S. war powers and presidential decision-making on the use of force would necessarily make any such uses of force more compliant with existing international customary or treaty law on the use of force, but rather that, without any significant Congressional involvement in war-making decisions, presidential decisions to use force, and the accompanying interpretation of the relevant law, acquire even more importance. Furthermore, 'almost all courts have held that the president and other high-level executive officers (such as the Attorney General) have the domestic legal authority to violate CIL. ${ }^{96}$

\footnotetext{
${ }^{65}$ Bradley and Goldsmith, 'Presidential Control over International Law', 1228.

${ }^{66}$ Weisburd, 'The Executive Branch and International Law', 1254.

${ }^{67} 376$ U.S. 398, 432-33 (Banco Nacional de Cuba v. Sabbatino) (1964). Regarding judicial interference in the practice of Presidents with respect to customary international law, Weisburd argues that: '... since the President acts as the primary American legislator in the field of customary international law by determining the day-to-day practice of the United States, judicial efforts to control that practice on nonconstitutional grounds amount to interference with legislative discretion vested in the President by the Constitution. The field of legislation is different - international as opposed to domestic law - but the constitutional question is the same. By giving the President control of most of the state practice of the United States, the Constitution vested the President with legislative discretion to cast the "vote" of the United States in matters of customary law.'

${ }^{68}$ Bradley, International Law in the U.S. Legal System, 296.
} 
The expansion of executive branch war powers and its influence over the interpretation of international law cannot be explained away by congressional inaction or presidential whims alone. One of the key elements that has led to the accretion of executive branch powers is the centrality of national security in U.S. political life.

\section{THE CENTRALITY OF NATIONAL SECURITY IN U.S. POLITICAL LIFE}

'Security against foreign danger is one of the primitive objects of civil society. It is an avowed and essential object of the American Union. ${ }^{69}$

Security is one of the overarching and primary concerns in U.S. national and political life. As Roxanne Dunbar-Ortiz puts it, '[T]he United States has been at war every day since its founding, often covertly and often in several parts of the world at once. ${ }^{70}$ A national preoccupation with matters of war and security was in evidence during the creation of the U.S. Constitution, and can be traced even further back in history than this. ${ }^{71}$ The early colonists and their communities perpetuated and experienced extreme violence, and 'the likelihood of violent consequences was never far from their minds. ${ }^{72}$ For example, there were striking parallels between the earlier occupation of Ireland and the occupation of North America, ${ }^{73}$ and for approximately a century, from 1650 to about 1750, 'the English colonists in North America

\footnotetext{
${ }^{69}$ Federalist No. 4. Available at: https://www.congress.gov/resources/display/content/The+Federalist+Papers.

${ }^{70}$ Roxanne Dunbar-Ortiz, 'What White Supremacists Know', 20 November 2018, available at: http://bostonreview.net/race/roxanne-dunbar-ortiz-what-white-supremacists-know (20 October 2020).

${ }^{71}$ The 'provision of security through restraint on violence' was one of the Framers' primary goals, with security an overarching issue at the Philadelphian Constitutional Convention in 1787. See: Daniel Deudney, Bounding Power: Republican Security Theory from the Polis to the Global Village (Princeton, 2007) 163.

${ }^{72}$ John Shy, 'The American Military Experience: History and Learning' The Journal of Interdisciplinary History 1 (2) (1971), 205-228: 212.

${ }^{73}$ Natsu Taylor Saito, Meeting the Enemy: American Exceptionalism and International Law (New York, 2010) 58.
} 
found themselves re-enacting on a small scale the horrors of Irish pacification and the Thirty Years War. ${ }^{74}$

American colonies experienced warfare 'less in terms of protection, of somehow insulating society against external violence...than in terms of retribution, of retaliating against violence already committed. ${ }^{75}$ This perception has stayed the course of American history. Appy describes the 'single potent assumption' upon which stories of American victimhood are based: 'our innocence and their treachery. ${ }^{97}$

Similarly, writing on the aftermath of $9 / 11$, Sherry refers to 'a belief that had long undergirded America's militarization':

'whatever military system it had, its leaders presented it as forced on them by enemies - not America's choice, not America's doing, not done in the pursuit of power or in blind rage but in the interest of protection. ${ }^{, 77}$

Since the beginning of the Cold War and the advent of a modern system of global capitalism dominated by the U.S., war-making in particular has helped to strengthen the centralised American state and the Executive Branch. ${ }^{78}$

Bacevich identifies four premises that have steered U.S. military policy since the end of the Cold War, which did not, as might have been expected, result in demobilisation: ‘ ... a broad (if unratified) consensus regarding the inherent desirability of military power; a commitment to maintaining U.S. global military supremacy in perpetuity; and support for maximising the

\footnotetext{
${ }^{74}$ Shy, 'The American Military Experience', 213.

${ }^{75}$ Shy, 'The American Military Experience', 213.

${ }^{76}$ Christian G. Appy, American Reckoning: The Vietnam War and Our National Identity (New York, 2015), 228.

${ }^{77}$ Michael Sherry, 'American Wars, Barely Visible to Americans', 30 March 2015, available at: http://www.booksandideas.net/American-Wars-Barely-Visible-to-Americans.html, (20 October 2020).

${ }^{78}$ Daniel Deudney and Sunil Vaswani, 'First in Freedom: War-Making, American Liberal International Identity and the Liberty Gradient', in Gunther Hellmann and Knud Erik Jørgenson (eds.) Theorizing Foreign Policy in a Globalized World (Hampshire and New York, 2015), 223-250: 233.
} 
utility of U.S. military might by pursuing an ambitious, activist agenda', as well as the maintenance of the international order, 'thereby enabling the processes of globalization to continue and the American people to reap its rewards. ${ }^{979}$ Coupled with 'a fundamental selfconfidence in the ability to fight', ${ }^{80}$ this contributes to what Young identified as a conviction:

'...that American power is such that it must prevail in any situation in which it has declared an interest; that the only obstacle to its triumph is the lack of determination to use that power.' 81

This imagined national identity, strongly informed by a belief in valorous war-making for the furthering of 'fundamental freedoms', combined with the militarisation of U.S. society and the United States' approach to military security, has had a profound impact on America's relationship with its domestic war powers and international law. Calls from successive U.S. presidents advocating for the complete eradication of terrorism and terrorist threats against the U.S., for example, invoke an absolutist approach to national security that is unlikely to be constrained by international law. 'State identity shapes states interests which in turn shape policy over time', and the tensions inherent in the founding myths of the U.S. - that of being an exceptional state which nonetheless embodies 'universal' values and therefore must be protected - come to the fore in the country's relationship with its executive branch and with international law. ${ }^{82}$ Where international law impedes or frustrates U.S. action, the U.S. tends to either ignore it and act anyway, as in the case of President Trump's strikes in Syria against

\footnotetext{
${ }^{79}$ Bacevich, The New American Militarism, 128.

${ }^{80}$ Shy, 'The American Military Experience', 221. For example, the first formal speech at the Philadelphia Convention, by Edmund Randolph, a representative for Virginia (who would later become the first United States Attorney General), criticised the existing Confederation for producing 'no security against foreign invasion', and its inability to 'check the quarrels between states, nor a rebellion in any'. See: Bruce D. Porter, War and the Rise of the State: The Military Foundations of Modern Politics (New York, 1994) 642.

${ }^{81}$ Marilyn B. Young, 'Bombing Civilians from the Twentieth to the Twenty-First Centuries' in Yuki Tanaka and Marilyn B. Young (eds.) Bombing Civilians: A Twentieth Century History (New York, 2010), 154-174:167. ${ }^{82}$ Mlada Bukovansky, 'American Identity and Neutral Rights from Independence to the War of 1812' International Organization 51 (2) (1997), 209-243: 210.
} 
the Syrian government, or in the assassination of Soleimani; or attempts to reconcile its unlawful positions with international law through the use of legalistic language, $a$ la the targeted killing programme. ${ }^{83}$

This equivocal relationship with international law has been in evidence since the formal founding of the United States. The 'founding fathers' attempted to secure the United States from external threats 'by gaining recognition from the European powers of its independence and rights under international law. ${ }^{94}$ As such, 'the early American Republic embraced...the law of nations as a means of consolidating the sovereignty of its people and securing its place among an international society of sovereign states. ${ }^{85}$ It was also a strong supporter of the institutions of international society, as they afforded the U.S. 'some relief from European predation. ${ }^{86}$ However, in invoking the law of nations, the 'founding fathers' were also immediately coming into conflict with that law. At that time, there was no right of selfdetermination under international law and colonies did not have a right to rebel, and it was therefore not possible to base their claims for independence in legal terms. ${ }^{87}$

'[T]he international law they invoked...explicitly privileged the rights of colonizing powers over Indigenous peoples, and in asserting a legal right to rebel under these conditions the colonial leaders certainly were not prepared to recognize a similar right of American Indians to self-determination. ${ }^{88}$

\footnotetext{
${ }^{83}$ See, for example, Catherine Connolly, 'Necessity Knows No Law: The Resurrection of Kriegsraison through the U.S. Targeted Killing Programme', Journal of Conflict and Security Law 22 (3) (2017), 463-496.

${ }^{84}$ Deudney, Bounding Power, 167.

${ }^{85}$ Jason G. Ralph, 'Republic, Empire or Good International Citizen? International law and American identity', in Kenneth Christie (ed.), United States Foreign Policy and National Identity in the $21^{\text {st }}$ Century (London and New York, 2008), 85-100: 85.

${ }^{86}$ Deudney, Bounding Power, 167.

${ }^{87}$ Taylor Saito, Meeting the Enemy, 71.

${ }^{88}$ Taylor Saito, Meeting the Enemy, 71.
} 
Notably, one of the grounds on which the revolutionaries claimed a right of self-determination was by proffering the accusation that the British monarch's actions 'were leaving them unprotected against "the merciless Indian Savages whose known rule of warfare, is an undistinguished destruction of all ages, sexes, and conditions." "89 The United States, then, has been creating exceptions to the application of international law to itself on the grounds of security since the state's creation.

Attempting to inflict lawfulness through violence has been a characteristic of colonialism throughout its history. Violence, after all, is integral to the process of colonial accumulation. That the violence of U.S. military engagements and operations around the world today often takes place under the guise of upholding or promoting the international rule of law does not lessen its neo-colonial qualities. The U.S. often achieves foreign and defence policy goals while remaining observant of relevant international legal rules. Other actions, such as the targeted killing programme, decided within the executive branch of U.S. government and justified in the name of necessity and self-defence, and which go far beyond what the law sanctions, are available to the U.S. because these actions take place outside the 'west' or the 'Global North'. An ahistoricism typical of imperialism also accompanies such actions; consider, for example, President Trump's statement on his administration's strikes on Syria in April 2018, in response to alleged chemical weapons use by pro-Assad forces. Trump deemed the Middle East a 'troubled place', stating that the U.S. will 'try to make it better' - failing to acknowledge how U.S. actions have contributed to making the Middle East the 'troubled place' it is today. ${ }^{90}$

In practice, the imperial character of U.S. international legal interpretation and defence policy has changed very little between administrations. Whether a U.S. president is a Democrat or a

\footnotetext{
${ }^{89}$ Taylor Saito, Meeting the Enemy, 71.

90 The White House, Statement by President Trump on Syria, 13 April 2018, available at:

https://www.whitehouse.gov/briefings-statements/statement-president-trump-syria/ (20 October 2020).
} 
Republican has mattered little in terms of how the U.S. approaches and practices defence policy, such is the level of militarisation in U.S. society, and the continued bipartisan support for U.S. military hegemony. There is no other state in the current international system that can more successfully repel aggression, and no other state has proven more capable at organising for what it deems 'self-defence'. The expansion of executive branch war powers, and the president's unchallenged authority in decisions on the use of force and international law interpretation, allow for prompt uses of force in situations which presidents regard as politically expedient or advantageous to U.S. interests, whether or not U.S. national security is actually under threat.

\section{CONCLUSION}

'The accretion of central power in America has occurred most easily during wars', wrote Porter in $1994 .{ }^{91}$ Now in a near-permanent state of war, executive branch war powers appear almost unlimited. The accretion of executive power cannot be considered at a remove from the society in which the US government operates: US political elites' obsession with war and security, so effectively tied up with US national identity, has been a primary factor in the expansion of this power. Coupled with the remove at which the majority of US citizens experience armed conflict - that is to say, not at all - presidents have been able to accrue more and more 'flexibility' in the area of war. As Dudziak notes, 'a president's ability, albeit imperfect, to shape the way Americans perceive war is a tremendously important aspect of presidential war power.' ${ }^{92}$ Successive US presidents have used both the debate over executive branch war powers and international law as smokescreens for unlawful uses of force. For instance, the U.S. was particularly vocal about the lawfulness of its actions under the international law on the recourse to force and the law of armed conflict under the Obama administration, going so far

\footnotetext{
${ }^{91}$ Porter, War and the Rise of the State, 521.

92 Dudziak, 'Death and the War Power', 60.
} 
as to assert that the administration held its drone strikes to higher targeting standards than those required by international humanitarian law. ${ }^{93}$ Where the Bush administration asserted the war on terror's legitimacy to justify its internationally unlawful conduct to an electorate eager to see forceful action against those responsible for the 9/11 attacks, the Obama administration asserted its legality for an electorate jaded by war and aware of the scandals of Guantanamo Bay, torture and rendition. Meanwhile, the Trump administration shies away from clear statements and discussions about the international legality or the legitimacy of its conduct, with his primary constituency viewing international law as inherently 'foreign' and anti-American. Appeals to national security and presidential prerogative instead fulfil this role.

An illustration of this can be found in the reports submitted to Congress under the WPR reporting requirements. The Obama administration submitted twenty-eight reports to Congress under the WPR, eight of which concerned hostilities or imminent hostilities. All eight referenced an international legal basis for the action in question. The Trump administration has submitted four reports to Congress, two of which relate to hostilities or imminent hostilities. None of the four reports provides an international law basis for the actions described in the reports. ${ }^{94}$

Whether a U.S. president is a Democrat or a Republican matters little in terms of how presidents interpret executive war powers. Of the 105 reports made to Congress under the WPR since 1973, ninety-seven of these reports claim that, in each of these instances, the president's domestic legal authority was derived from Article II of the Constitution alone. Sixty-five of these reports claiming such constitutional authority came from Democratic Party presidents. ${ }^{95}$

\footnotetext{
${ }^{93}$ Jennifer M. O' Connell, 'Applying the Law of Targeting to the Modern Battlefield', 28 November 2016, availale at: https://dod.defense.gov/Portals/1/Documents/pubs/Applying-the-Law-of-Targeting-to-the-ModernBattlefield.pdf (20 October 2020).

${ }^{94}$ War Powers Resolution Reporting Project, 48-Hour Report Database, 2020, available at: https://warpowers.lawandsecurity.org/findingsandanalysis/ (19 October 2020).

${ }^{95}$ War Powers Resolution Reporting Project.
} 
Primary differences are found instead in terms of how defence policies are framed and presented to either Democratic or Republican electorates, and whether and how this framing makes appeals to, or references, international law. Given the significant military power of the US, this has direct consequences for the international law on the use of force.

Successive U.S. presidents have proclaimed the might of the U.S. military, and it is regularly exalted as being the most powerful in history. In a speech at Fort Drum, on August 13 2018, Trump stated that '...no enemy on Earth can match the strength, courage, and skill of the American Army and the American Armed Forces. Nobody is even close. They never will be. ${ }^{96}$ This extraordinary focus on the military might of the U.S. is matched by key figures in the Democratic Party. For example, Joe Biden's presidential campaign website, under the heading 'defend our vital interests', carries the following message: 'As president, Biden will never hesitate to protect the American people, including when necessary, by using force. We have the strongest military in the world — and as president, Biden will ensure it stays that way. ${ }^{97}$

Assurances from both parties that neither will seek to diminish the standing of the US military demonstrates bipartisan consensus on one of the key issues in US domestic life relevant to the international law on the use of force. With 'security' at the political level tied to military necessity at the operational level, the US executive is encouraged to seek out figures, groups and territories that could potentially cause the state harm, or that could be perceived as threatening its interests, however broadly defined. And, as Neocleous observes, 'the presupposition of permanent threat - to the warpower, to the social order, to human being demands a constant reimagining of the myriad ways in which the threat might be realised. ${ }^{98}$

\footnotetext{
${ }^{96}$ US Department of Defense, 'FYI 2019 Defense Budget', 2019, available at: https://dod.defense.gov/News/SpecialReports/Budget2019.aspx (20 October 2020).

${ }^{97}$ Biden-Harris campaign, 'The power of America's example: the Biden plan for leading the democratic world to meet the challenges of the $21^{\text {st }}$ Century', 2020, available at: , https://joebiden.com/americanleadership/ (20 October 2020).

${ }_{98}$ Mark Neocleous, War Power, Police Power (Edinburgh, 2014), 199.
} 
This encourages the executive to address these potential threats through forceful and violent means. It can do so with great ease: the US continues to have a significant global military presence, with military bases in approximately 80 states, ${ }^{99}$ and an estimated $200,000^{100}$ troops in 170 countries. ${ }^{101}$

Rather than looking only at what the end results of these 'reimaginings' are - at the thousands of deaths resulting from the targeted killing programme, for example, or at the steady erosion of international law principles such as non-intervention, and the attempted broadening of the right to use force in self-defence - we also need to ask what interests these choices serve. Accepting attempts to make the decisions behind many of these issues look like questions of law, rather than questions of politics, hides the irreducibly political choices behind them. If war is the continuation of politics by other means, then we must examine the politics and the origins of these politics. ${ }^{102}$ In the United States, these politics are inextricably informed by and entwined with the country's history of settler-colonialism and racial discrimination, and, since at least the end of WWII, its pursuit of global economic and military hegemony. ${ }^{103}$

\footnotetext{
${ }^{99}$ The Nation, 'The US has military bases in 80 countries. All of them must close', 24 January 2018, available at: https://www.thenation.com/article/archive/the-us-has-military-bases-in-172-countries-all-of-them-mustclose/ (20 October 2020).

${ }^{100} \mathrm{Al}$ Jazeera, 'Counting the cost of US military bases around the world', 12 January 2020, available at: https://www.aljazeera.com/program/counting-the-cost/2020/1/12/counting-the-cost-of-us-military-bases-aroundthe-world/ (20 October 2020).

${ }^{101}$ The New York Times, 'America has no reason to be so powerful', 15 October 2020, available at: https://www.nytimes.com/2020/10/15/opinion/america-global-power.html (20 October 2020).

${ }^{102}$ Carl Von Clausewitz, On War (Princeton, 1976), 87.

${ }^{103}$ It should be noted that international law itself is also complicit in, and continues to be informed by, these processes. See, for example, Rob Knox, 'Valuing Race? Stretched Marxism and the Logic of Imperialism' London Review of International Law 4 (1) (2016), 81-126: 92.
} 